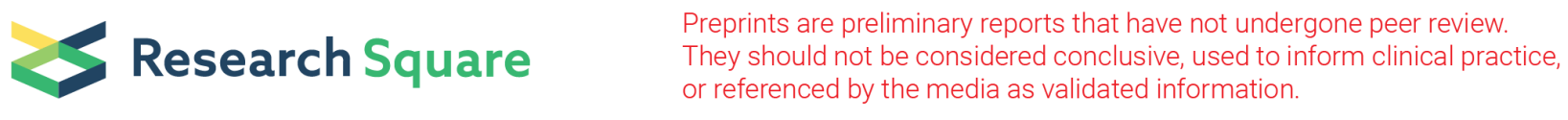

\title{
Ocular Manifestation of Elizabethkingia Meningoseptica
}

KAI CHING PETER LEUNG ( $\square$ heyays@gmail.com )

Tung Wah Eastern Hospital https://orcid.org/0000-0001-6371-7656

TAK CHUEN SIMON KO

TUNG WAH EASTERN HOSPITAL

Original research

Keywords: Elizabethkingia, Elizabethkingia meningoseptica, conjunctivitis, keratitis, blepharitis

Posted Date: May 29th, 2020

DOI: https://doi.org/10.21203/rs.3.rs-31273/v1

License: (9) (1) This work is licensed under a Creative Commons Attribution 4.0 International License. Read Full License 


\section{Abstract}

Background: Elizabethkingia is a Gram-negative, obligate aerobic, oxidase positive bacillus that is known to cause a variety of nosocomial infections and has emerged as an important pathogen because of multiple anti-microbial resistance. We present the largest case series of Elizabethkingia ophthalmic infections, with specific emphasis on its clinical spectrum, risk factors, treatment and outcome.

Method: Microbiological specimens growing Elizabethkingia were reviewed retrospectively at a regional tertiary hospital from 2005-2019. Clinical manifestation, risk factors, treatment including types of antibiotics, treatment duration and clinical outcome were documented.

Results: Ten cases of culture positive Elizabethkingia ophthalmic infection were identified, which all cultured E. meningoseptica. Four cases keratitis, three cases of conjunctivitis, two cases of blepharitis and one case blepharitis-conjunctivitis were observed. Four cases were found to be associated with contact lens use and were found to colonize $E$. meningoseptica. One case of blepharitis was associated with and ocular prosthesis (scleral shell) an eviscerated eye. Fluoroquinolone and chloramphenicol were most commonly used topical antibiotics for treatment. The mean treatment duration for all infections was averaged at 6.5 weeks.

Conclusion: E. meningoseptica is found to be the predominant species that has caused infection at the ocular surface. Contact lens use and ocular prosthesis appears to be a risk factor for infection due to ocular surface barrier disruption and bacteria colonization. Combination of fluroquinolone and chloramphenicol is a safe and effective treatment against Elizabethkingia ocular infections. Further studies are required to determine the susceptibility of commonly used topical anti-microbial agents to Elizabethkingia species.

\section{Introduction}

Elizabethkingia is a Gram-negative, obligate aerobic, oxidase positive, non-glucose fermenting bacillus that is widely available in nature and is increasingly being identified to survive on hospital surfaces and medical equipment [1-4]. Elizabethkingia is known to cause a variety of nosocomial human infections and has emerged as a clinically important pathogen because of its resistance to multiple anti-microbial agents [4-7]. Ophthalmological related Elizabethkingia infections are increasingly being reported where use of contact lens, trauma, ocular surgery and ocular surface disorders were associated [811]. Standardized management, choice of anti-microbial treatment and prognosis of Elizabethkingia ocular infections are lacking due to paucity of cases. We present the largest case series of Elizabethkingia induced ophthalmic infections, with specific emphasis on its clinical spectrum, risk factors, treatment and outcome.

\section{Materials And Methods}

Microbiological specimens growing Elizabethkingia were reviewed retrospectively in a regional tertiary hospital from 2005-2019. Positive Elizabethkingia isolates from eye swabs, corneal scrapping and bacterial culture for contact lens in respective cases were retrieved from the hospital microbiological database. All clinical specimens were collected and handled according to standard protocols. Elizabethkingia was first identified by conventional phenotypic method. Gram-negative bacilli were initially recovered from the specimens. These isolates were incubated on sheep blood agar for 24 hours which gave rise to yellowish, semi-translucent, convex shaped small colonies. No growth was observed after incubation on MacConkey agar. Extracted non-motile Gram-negative rods were then examined biochemically that yielded catalase positivity and oxidase positivity, which were further characterized using VITEK GN (Gramnegative) card and matrix-assisted laser-desorption/ionization time-of- flight mass spectrometry (MALDI-TOF-MS) VITEK-2 system (Biomerieux Vitek, Hazelwood, MO, USA). Acanthamoeba and fungi were also tested on all cases using direct microscopy, polymerase chain reaction (PCR) and real-time PCR. Antibiotic susceptibility of the samples was not examined as VITEK-2 system Gram negative antibiotic testing card at the institution do not cover most of the topical antibiotics used in the cases.

Clinical data and hospital charts were reviewed retrospectively. Patient demographics including age, gender and past medical history were recorded. Diagnosis were clinical and supplemented by microbiological finding. Treatment including types of antibiotics, total number of antibiotics used, treatment duration and clinical outcome were documented. The study has received approval from the hospital ethics committee and adhere to the principles of the Declaration of Helsinki.

\section{Results}

Thirteen cases of culture positive Elizabethkingia species in ocular microbiological specimen were identified. Two cases were excluded because of lost to follow up. One case was excluded due to incomplete data. The mean age of patients being infected by Elizabethkingia was 57 years old (age range 16 days old- 91 years old). The female to male ratio was 6:4. One patient had a history of underlying pancytopenia, bullous pemphigoid and pre-existing type 2 diabetes. Three other patients had co-existing type 2 diabetes and ischemic heart disease. No apparent immunosuppressive states were noted in others.

The findings were summarized in the Table 1. All ten cases have cultured E. meningoseptica and tested negative for fungal infection. Case 6 and 8 showed coisolates of coagulase negative Staphylococcus. Four eyes resulted in keratitis, where three eyes were affected by conjunctivitis, two by blepharitis and one by concurrent blepharitis- conjunctivitis. 


\begin{tabular}{|c|c|c|c|c|c|c|c|c|c|}
\hline $\begin{array}{l}\text { NUMBER } \\
\text { OF } \\
\text { PATIENTS }\end{array}$ & $\begin{array}{l}\text { AGE } \\
\text { (years } \\
\text { old) }\end{array}$ & GENDER & CULTURE & DIAGNOSIS & BACKGROUND & $\begin{array}{l}\text { ANTIBIOTICS } \\
\text { EYE DROP }\end{array}$ & $\begin{array}{l}\text { ORAL } \\
\text { ANTIBIOTICS }\end{array}$ & $\begin{array}{l}\text { DURATION } \\
\text { OF } \\
\text { TREATMENT } \\
\text { (WEEKS) }\end{array}$ & $\begin{array}{l}\text { RISK } \\
\text { FACTOR }\end{array}$ \\
\hline 1 & 36 & M & $\begin{array}{l}\text { Elizabethkingia } \\
\text { meningoseptica }\end{array}$ & $\begin{array}{l}\text { Keratitis; } \\
\text { Corneal } \\
\text { abscess }\end{array}$ & $\mathrm{Nil}$ & $\begin{array}{l}\text { Levofloxacin; } \\
\text { ofloxacin; } \\
\text { chloramphenicol }\end{array}$ & None & 4 & $\begin{array}{l}\text { Contact } \\
\text { lens } \\
\text { Trauma }\end{array}$ \\
\hline 2 & 55 & $\mathrm{~F}$ & $\begin{array}{l}\text { Elizabethkingia } \\
\text { meningoseptica }\end{array}$ & Blepharitis & $\begin{array}{l}\text { Eviscerated } \\
\text { eye secondary } \\
\text { to conjunctival } \\
\text { tumor. Orbital } \\
\text { prosthesis } \\
\text { (scleral shell) } \\
\text { in situ }\end{array}$ & $\begin{array}{l}\text { Levofloxacin; } \\
\text { chloramphenicol }\end{array}$ & Ciprofloxacin & 6 & $\begin{array}{l}\text { Orbital } \\
\text { prosthesis } \\
\text { artificial } \\
\text { eye }\end{array}$ \\
\hline 3 & 32 & M & $\begin{array}{l}\text { Elizabethkingia } \\
\text { meningoseptica }\end{array}$ & Keratitis & $\mathrm{Nil}$ & $\begin{array}{l}\text { Chloramphenicol; } \\
\text { levofloxacin; } \\
\text { ofloxacin; } \\
\text { gentamicin }\end{array}$ & Ciprofloxacin & 12 & $\begin{array}{l}\text { Contact } \\
\text { lens }\end{array}$ \\
\hline 4 & 45 & $\mathrm{~F}$ & $\begin{array}{l}\text { Elizabethkingia } \\
\text { meningoseptica }\end{array}$ & Keratitis & Nil & $\begin{array}{l}\text { Moxifloxacin; } \\
\text { ofloxacin; } \\
\text { gentamicin; } \\
\text { fusidic acid }\end{array}$ & Doxycycline & 10 & $\begin{array}{l}\text { Contact } \\
\text { lens }\end{array}$ \\
\hline 5 & 42 & $\mathrm{~F}$ & $\begin{array}{l}\text { Elizabethkingia } \\
\text { meningoseptica }\end{array}$ & Keratitis & Nil & $\begin{array}{l}\text { Levofloxacin; } \\
\text { ofloxacin }\end{array}$ & $\begin{array}{l}\text { Clarithromycin; } \\
\text { doxycycline }\end{array}$ & 6 & $\begin{array}{l}\text { Contact } \\
\text { lens }\end{array}$ \\
\hline 6 & 91 & $\mathrm{~F}$ & $\begin{array}{l}\text { Elizabethkingia } \\
\text { meningoseptica }\end{array}$ & $\begin{array}{l}\text { Blepharitis- } \\
\text { conjunctivitis }\end{array}$ & $\begin{array}{l}\text { Type } 2 \\
\text { diabetes; } \\
\text { ischemic heart } \\
\text { disease }\end{array}$ & $\begin{array}{l}\text { Levofloxacin; } \\
\text { fusidic acid }\end{array}$ & None & 4 & $\begin{array}{l}\text { Post } \\
\text { cataract } \\
\text { surgery } 6 \\
\text { weeks }\end{array}$ \\
\hline 7 & $\begin{array}{l}16 \\
\text { days }\end{array}$ & M & $\begin{array}{l}\text { Elizabethkingia } \\
\text { meningoseptica }\end{array}$ & Conjunctivitis & $\mathrm{Nil}$ & $\begin{array}{l}\text { Chloramphenicol; } \\
\text { neosporin }\end{array}$ & None & 7 & None \\
\hline 8 & 68 & M & $\begin{array}{l}\text { Elizabethkingia } \\
\text { meningoseptica }\end{array}$ & Blepharitis & $\begin{array}{l}\text { Pancytopenia; } \\
\text { Type 2 } \\
\text { diabetes; } \\
\text { bullous } \\
\text { pemphigoid }\end{array}$ & $\begin{array}{l}\text { Levofloxacin; } \\
\text { tobramycin }\end{array}$ & None & 6 & None \\
\hline 9 & 57 & $\mathrm{~F}$ & $\begin{array}{l}\text { Elizabethkingia } \\
\text { meningoseptica }\end{array}$ & Conjunctivitis & $\begin{array}{l}\text { Type 2 } \\
\text { diabetes; } \\
\text { ischemic heart } \\
\text { disease; heart } \\
\text { failure; }\end{array}$ & $\begin{array}{l}\text { Chloramphenicol; } \\
\text { moxifloxacin }\end{array}$ & None & 6 & None \\
\hline 10 & 83 & $\mathrm{~F}$ & $\begin{array}{l}\text { Elizabethkingia } \\
\text { meningoseptica }\end{array}$ & Conjunctivitis & $\begin{array}{l}\text { Type } 2 \\
\text { diabetes; } \\
\text { congestive } \\
\text { heart failure }\end{array}$ & $\begin{array}{l}\text { Chloramphenicol; } \\
\text { fusidic acid }\end{array}$ & Nil & 4 & None \\
\hline
\end{tabular}

Table 1

Summary of clinical syndrome associated with Elizabethkingia associated ocular infection and treatment outcome.

All four cases of keratitis were associated with contact lens use, with one case of keratitis complicated by development of corneal abscess secondary to trauma to the eye. Three blepharitis cases were recorded, where one case of blepharitis had a history of evisceration and an ocular prosthesis (scleral shell) in situ, one had a history of pancytopenia and bullous pemphigoid, whilst another one developed blepharitis six weeks after same eye cataract operation whilst using topical steroids for prolonged anterior chamber inflammation. Three cases of conjunctivitis were recorded, in which two cases had a background of type 2 diabetes and history of heart disease. No cases of conjunctivitis had reported use of contact lens or trauma prior to infection. The clinical outcome of conjunctivitis and blepharitis were satisfactory with clinical resolution after treatment. All keratitis cases resulted in corneal scar.

Contact lens were also examined microbiologically in all respective cases. Four cases have cultured E. meningoseptica. Tests for fungal infection in all cases were negative.

All cases in the study were treated with topical medications in drop and ointment form. The average number of topical antibiotics class used were two (range 2-4). Fluoroquinolone (levofloxacin, moxifloxacin, ofloxacin) and chloramphenicol were most commonly used topical antibiotics for treatment. Topical Fusidic acid, Gentamicin and Neosporin were added in five other cases. Four cases of ocular infection included systemic oral antibiotics (ciprofloxacin, doxycycline and clarithromycin) as part of the treatment regime (three cases of keratitis, one case of blepharitis with ocular prosthesis in situ). The average duration of treatment were 6.5 weeks (range 4-12 weeks).

\section{Discussion}

Elizabethkingia is an important saprophyte that has grown much attention in recent years due to its ability to cause clinically significant infections and resistance to multiple anti-microbial agents [1-4]. Limited cases of ocular Elizabethkingia infections have been reported, where contact lens use, trauma, previous ocular surgery and ocular surface disorders appeared to be important risk factors [8-12]. We present the largest series of Elizabethkingia infection 
that has manifested in eyes. The spectrum of Elizabethkingia ocular infections is wide and mostly confined to the ocular surface. In our series, $40 \%$ (4/10) of cases resulted in keratitis, whereas $30 \%(3 / 10)$ caused conjunctivitis, $20 \%$ blepharitis $(2 / 10)$ and $10 \%$ as concurrent blepharitis- conjunctivitis ( $1 / 10)$. The clinical characteristics of Elizabethkingia echoed with previous reports and is found confined to the ocular surface. Previously reported Elizabethkingia induced endophthalmitis was not found in our series and no intraocular infections were identified [13, 14]. To date, six species of Elizabethkingia have been identified: E. meningioseptica, E. miricola, E. anopheles, E. bruuniana, E. ursingii, and E. occultia [15]. E. anopheles has traditionally been shown to be the predominant strain that causes life threatening bacteremia and neonatal meningitis, where $E$. meningoseptica and $E$. miricola are known to cause biliary tract infections [16]. In our series, E. meningoseptica has been established to be the major species that caused ocular infection. The reason for the "ophthalmic strain" and predominance is unknown and yet to be determined.

The association of Elizabethkingia induced keratitis and contact lens is demonstrated in our study. Contact lens predisposes the cornea to microtrauma and hypoxia which disrupted the corneal epithelium and barrier to bacterial binding. In addition, biofilm formation and pathogen colonization on contact lens also potentiated the infection. This is confirmed in our study, where respective contact lens has cultured the same pathogen. The ability of Elizabethkingia to attach on contact lens, cases and water supplies is an important factor for development of ocular infections [3, 4]. Mechanisms including substandard contact lens hygiene, extended wear and trauma may also play a role in the potentiating the infection.

The association between orbital surgery and Elizabethkingia infection are also being reported for the first time. Previous reports have documented Elizabethkingia infections to occur after intraocular surgeries e.g. penetrating and lamellar keratoplasty [17, 18]. The authors believed history of previous orbital surgeries may be linked with development of ocular surface Elizabethkingia infections. In our case, an eviscerated eye with an ocular prosthesis (scleral shell) presents as a risk factor for development of blepharitis, as E. meningoseptica may have colonized the foreign body and acted as a reservoir for the pathogen. We speculate that the uneven surface of the acrylic prosthesis allowed bacterial attachment and subsequent biofilm formation, which created a barrier against removal from normal cleansing and sterilization.

The use of topical steroids in the post-operative cataract period may also be linked to E. meningoseptica blepharitis. Prolonged topical steroid was prescribed in our case due to anterior chamber inflammation. We suspect that the treatment aggravated the development of Elizabethkingia blepharitis, as topical steroid has been shown to delay epithelial healing and inhibit neutrophil activation, which subsequently weakened the ocular surface protective barrier [19, 20]. While chronic co-morbidities have been shown to cause Elizabethkingia systemic infections, in our series we could not establish a strong relationship, with only $40 \%$ (4/10) of cases identified to have significant past medical histories [21].

Established reports of antibiotics susceptibility on Elizabethkingia species have shown resistance to ceftazidime, imipenem and aminoglycosides and susceptibility to ciprofloxacin, cefoperazone-sulbactam and vancomycin treatments $[16,22,23]$. The multiple anti-microbial resistance in Elizabethkingia is conferred in $\beta$-lactams as a result of possession of Ambler class A serine extended-spectrum $\beta$-lactamase (ESBL) gene bla $\mathrm{CME}_{\mathrm{C}}$ and Ambler class $\mathrm{B}$ metallo- $\beta$ lactamase (MBL) genes bla $\mathrm{BlaB}_{\mathrm{B}}$ and $\mathrm{bla}_{\mathrm{GOB}}[24,25]$. Resistance is also seen in quinolones secondary to genetic mutations in DNA gyrase and topoisomerase IV [26]. Empirical treatment using fluoroquinolone, glycopeptide and third-generation cephalosporin with $\beta$-lactamase inhibitor have been advocated for treating systemic infections $[16,22,23]$.

There is currently no consensus on treatment for Elizabethkingia ophthalmic infections. Treatment of ocular infection frequently employ topical route of administration and susceptibility to commonly used topical antibiotics in ophthalmic practice, such as chloramphenicol and fusidic acid, have not been evaluated. Our series has demonstrated that combined use of 2 topical antibiotic, fluoroquinolone and chloramphenicol, could lead to safe and successful treatment of $E$. meningoseptica conjunctivitis, blepharitis and keratitis. The addition of systemic oral antibiotics such as oral quinolones, tetracycline or macrolide have shown to be effective. Levofloxacin, one of the commonly used topical fluoroquinolone in ophthalmological practice, contain a C-8 methoxy group that exert stronger antibacterial activity against fluoroquinolone-resistant bacteria that harbored QRDR mutations [27, 28]. Whether the single agent of topical fluroquinolone alone enabled treatment success or combination with topical chloramphenicol is not determined. Further studies are required to determine the susceptibility of chloramphenicol to Elizabethkingia species. A longer period of treatment for Elizabethkingia ocular surface infections was also observed, which averaged 6.5 weeks in our series. We speculate that this could be due to bacterial intracellular invasion, inability to break multicellular biofilm and ineffective ocular immunity $[3,29]$. This could be reflected in the outcome, where conjunctivitis, blepharitis and conjunctivitis-blepharitis confer excellent clinical recovery where keratitis all resulted in corneal scarring.

\section{Conclusion}

In summary, Elizabethkingia is an emerging organism that could manifest in eyes and is clinically challenging to treat due to its multiple anti-microbial resistance. In our series we have demonstrated that $E$. meningoseptica is the predominant species that causes infection at the ocular surface. Contact lens use and ocular prosthesis in situ appears to be a significant risk factor for development of ocular Elizabethkingia infections due to ocular surface barrier disruption and bacteria colonization. Contrary to previous beliefs, immunosuppressive state does not appear to be a significant factor for ocular infections. Combination of topical fluroquinolone and chloramphenicol is a safe and effective treatment regime for Elizabethkingia ocular infections. Further studies are required to establish the most effective treatment approach.

\section{Declarations}

\section{Ethics approval and consent to participate-}

not applicable 


\section{Consent for publication-}

not applicable

\section{Availability of data and material-}

not applicable

\section{Competing interest-}

The authors declare that they have no competing interests

\section{Funding-}

nil

\section{Acknowledgments:}

none

\section{References}

1. KING EO (1959) Studies on a group of previously unclassified bacteria associated with meningitis in infants. American journal of clinical pathology. https://doi.org/10.1093/ajcp/31.3.241

2. Kim KK (2005) Transfer of Chryseobacterium meningosepticum and Chryseobacterium miricola to Elizabethkingia gen. nov. as Elizabethkingia meningoseptica comb. nov. and Elizabethkingia miricola comb. nov. INTERNATIONAL JOURNAL OF SYSTEMATIC AND EVOLUTIONARY MICROBIOLOGY 55:1287-1293. https://doi.org/10.1099/ijs.0.63541-0

3. Liu LY, Seo J, McCanna DJ, et al (2016) Assessment of biofilm formation of E. meningoseptica, D. acidovorans, and S. maltophilia in lens cases and their growth on recovery media. Contact Lens and Anterior Eye. https://doi.org/10.1016/j.clae.2015.09.001

4. Lin P-Y, Chen H-L, Huang C-T, et al (2010) Biofilm production, use of intravascular indwelling catheters and inappropriate antimicrobial therapy as predictors of fatality in Chryseobacterium meningosepticum bacteraemia. International Journal of Antimicrobial Agents 36:436-440. https://doi.org/10.1016/j.ijantimicag.2010.06.033

5. Ceyhan M, Yıldırım I, Tekelı A, et al (2008) A Chryseobacterium meningosepticum outbreak observed in 3 clusters involving both neonatal and nonneonatal pediatric patients. American Journal of Infection Control 36:453-457. https://doi.org/10.1016/j.ajic.2007.09.008

6. Maraki S, Scoulica E, Manoura A, et al (2009) A Chryseobacterium meningosepticum colonization outbreak in a neonatal intensive care unit. European Journal of Clinical Microbiology \& Infectious Diseases 28:1415-1419. https://doi.org/10.1007/s10096-009-0797-2

7. Pereira GH, Garcia D de O, Abboud CS, et al (2013) Nosocomial infections caused by Elizabethkingia meningoseptica: An emergent pathogen. Brazilian Journal of Infectious Diseases. https://doi.org/10.1016/j.bjid.2013.02.011

8. Li EY, Jhanji V (2014) Massive lipid keratopathy after Elizabethkingia meningosepticum keratitis. Contact Lens and Anterior Eye 37:55-56. https://doi.org/10.1016/j.clae.2013.07.011

9. Yang YS eon., Chun JW oon., Koh JW oon. (2013) Keratitis with Elizabethkingia meningoseptica Occurring after Contact Lens Wear: A Case Report. Korean Journal of Ophthalmology 27:133. https://doi.org/10.3341/kjo.2013.27.2.133

10. Beato J, Espinar M, Figueira L, et al (2016) Elizabethkingia meningoseptica and Contact Lens Use. Acta Médica Portuguesa 29:287. https://doi.org/10.20344/amp.7048

11. Erdem E, Abdurrahmanoglu S, Kibar F, et al (2013) Posttraumatic Keratitis Caused by Elizabethkingia meningosepticum. Eye \& Contact Lens: Science \& Clinical Practice 39:361-363. https://doi.org/10.1097/ICL.0b013e318291d171

12. Ray M, Lim DK (2013) A rare polymicrobial keratitis involving chryseobacterium meningosepticum and delftia acidovorans in a cosmetic contact lens wearer. Eye and Contact Lens. https://doi.org/10.1097/ICL.0b013e3182448881

13. Pradeep BE, Mahalingam N, Manivannan B, et al (2014) Draft genome sequence of Elizabethkingia meningoseptica, isolated from a postoperative endophthalmitis patient. Genome Announcements. https://doi.org/10.1128/genomeA.01335-14

14. Connell PP, Wickremasinghe S, Devi U, et al (2011) Self-induced Elizabethkingia meningoseptica endophthalmitis: a case report. Journal of Medical Case Reports 5:303. https://doi.org/10.1186/1752-1947-5-303

15. Lin J-N, Lai C-H, Yang C-H, Huang Y-H (2019) Elizabethkingia Infections in Humans: From Genomics to Clinics. Microorganisms 7:295. https://doi.org/10.3390/microorganisms7090295

16. Lau SKP, Chow W-N, Foo C-H, et al (2016) Elizabethkingia anophelis bacteremia is associated with clinically significant infections and high mortality. Scientific Reports 6:26045. https://doi.org/10.1038/srep26045 
17. Bucci FA, Holland EJ (1991) Flavobacterium meningosepticum keratitis successfully treated with topical trimethoprim-sulfamethoxazole. American Journal of Ophthalmology

18. LeFrancois M (1976) Flavobacterium Endophthalmitis Following Keratoplasty. Archives of Ophthalmology 94:1907. https://doi.org/10.1001/archopht.1976.03910040617007

19. Chung J-H, Kang Y-G, Kim H-J (1998) Effect of 0.1\% dexamethasone on epithelial healing in experimental corneal alkali wounds: morphological changes during the repair process. Graefe's Archive for Clinical and Experimental Ophthalmology 236:537-545. https://doi.org/10.1007/s004170050118

20. Gritz DC, Lee TY, Kwitko S, McDonnell PJ (1990) Topical Anti-inflammatory Agents in an Animal Model of Microbial Keratitis. Archives of Ophthalmology. https://doi.org/10.1001/archopht.1990.01070090103049

21. Bloch KC, Nadarajah R, Jacobs R (1997) Chryseobacterium meningosepticum: An Emerging Pathogen Among Immunocompromised Adults Report of 6 Cases and Literature Review. Medicine. https://doi.org/10.1097/00005792-199701000-00003

22. Lin J-N, Lai C-H, Yang C-H, Huang Y-H (2018) Comparison of Clinical Manifestations, Antimicrobial Susceptibility Patterns, and Mutations of Fluoroquinolone Target Genes between Elizabethkingia meningoseptica and Elizabethkingia anophelis Isolated in Taiwan. Journal of Clinical Medicine. https://doi.org/10.3390/jcm7120538

23. Wang L, Zhang X, Li D, et al (2020) Molecular Characteristics and Antimicrobial Susceptibility Profiles of Elizabethkingia Clinical Isolates in Shanghai, China. Infection and Drug Resistance Volume 13:247-256. https://doi.org/10.2147/IDR.S240963

24. Bellais S, Poirel L, Naas T, et al (2000) Genetic-Biochemical Analysis and Distribution of the Ambler Class A beta -Lactamase CME-2, Responsible for Extended-Spectrum Cephalosporin Resistance in Chryseobacterium (Flavobacterium) meningosepticum. Antimicrobial Agents and Chemotherapy 44:1-9. https://doi.org/10.1128/AAC.44.1.1-9.2000

25. González LJ, Vila AJ (2012) Carbapenem resistance in Elizabethkingia meningoseptica is mediated by metallo- $\beta$-lactamase BlaB. Antimicrobial Agents and Chemotherapy. https://doi.org/10.1128/AAC.05835-11

26. Jian M-J, Cheng Y-H, Perng C-L, Shang H-S (2018) Molecular typing and profiling of topoisomerase mutations causing resistance to ciprofloxacin and levofloxacin in Elizabethkingia species. PeerJ 6:e5608. https://doi.org/10.7717/peerj.5608

27. Fu Y, Zhang W, Wang H, et al (2013) Specific patterns of gyr A mutations determine the resistance difference to ciprofloxacin and levofloxacin in Klebsiella pneumoniae and Escherichia coli. BMC Infectious Diseases 13:8. https://doi.org/10.1186/1471-2334-13-8

28. Lu T, Zhao X, Li X, et al (2001) Enhancement of fluoroquinolone activity by C-8 halogen and methoxy moieties: Action against a gyrase resistance mutant of Mycobacterium smegmatis and a gyrase-topoisomerase iv double mutant of Staphylococcus aureus. Antimicrobial Agents and Chemotherapy. https://doi.org/10.1128/AAC.45.10.2703-2709.2001

29. Lin PY, Chiu CH, Chu C, et al (2006) Invasion of murine respiratory tract epithelial cells by Chryseobacterium meningosepticum and identification of genes present specifically in an invasive strain. New Microbiologica 